\title{
Heinrich Himmler, Søren Telling og Danevirke
}

\author{
af JøRGEN KÜHL
}

Danevirke forbindes som regel med oldtidens og middelalderens forsvarsvolde og de skanser, der blev rejst op til krigen i 1864. Derudover har Danevirke dog også spillet en rolle i det 20. århundredes historie. I årene 1939-45 kom Danevirke i nazismens søgelys. SS-føreren Heinrich Himmler var personligt med til at sikre, at Danevirke ikke led overlast, og danskeren Soren Telling var involveret i forsøg på at forhindre et ødelæggende indgreb $i$ fortidsmindet i 1944, da der blev anlagt en pansergrav ved Danevirke. Museumsleder ved Danevirke-Museet, fra 1. aug. 1999 direktor for Institut for Grænseregionsforskning i Aabenraa Jørgen Kühl, sætter her fokus på træk af voldanlæggets historie $\mathrm{i}$ det 20 . århundrede. ${ }^{1}$

\section{Nazistisk arkæologi, Hedeby og Danevirke}

I 1864 sluttede Danmarks andel i Danevirkes historie; men selve voldanlægget skulle opleve et nyt kapitel, der hænger sammen med såvel ideologisk motiverede arkæologiske undersøgelser af voldanlægget som anlæggelsen af militære installationer i og foran Danevirke. ${ }^{2}$ Den tyske arkæologi var dybt involveret $i$ det nazistiske diktatur i Tyskland. ${ }^{3}$ De nazistiske magthavere nærede voldsom interesse for arkæologien. Arkæologien blev sammen med racelære og folkemindeforskning ophøjet til »Weltanschauungswissenschaften « og udgjorde dermed en del af den (pseudo-)videnskabelige legitimation for nazismen. ${ }^{4}$ Det gjaldt både indadtil i tiden 1933-39 og udadtil under Anden Verdenskrig 1939-45. Her blev arkæologerne særdeles aktive i de områder, der under krigen blev erobret og besat af Hitler-Tyskland. Tyske arkæologer plyndrede dels østeuropæiske museer og samlinger; dels gennemførte de storstilede udgravninger, der skulle dokumentere "germansk" kulturarv og kulturspor i disse nyerobrede dele af Østeuropa. Dermed skulle bl.a. den nazistiske Østpolitik legitimeres, der sigtede på en etnisk nyordning af Europa på grundlag af germanske befolkningskoncentrationer, der skulle fylde det tomrum, som opstod 
som følge af den systematiske udryddelse, fordrivelse og deportation af den hidtidige befolkning på stedet. Selv om de tyske arkæologer med rang af SS-officerer ikke selv aktivt deltog i folkedrabet, var de involveret $i$ hele den politik, som folkedrabet indgik $i$.

Imidlertid fandtes der ikke blot én, men hele to, indbyrdes konkurrerende arkæologiske institutioner i Hitler-Tyskland: Ahnenerbe (grundlagt i 1935) sorterede under Heinrich Himmler og SS. Her var også Hedeby-Danevirkeforskeren Herbert Jankuhn en aktiv frontfigur. SS-Ahnenerbe konkurrerede med den nazistiske chefideolog Alfred Rosenbergs institution "Amt Rosenberg ", hvor en særlig "Sonderstab Vorgeschichte“ (oprettet i 1934) ligeledes gennemførte arkæologiske udgravninger. Lederen af "Sonderstab Vorgeschichte var arkæologen Hans Reinerth, der samtidig stod i spidsen for »Reichsbund für Deutsche Vorgeschichte «. Dette forbund forsynede bl.a. skoler og museer med detaljerede modeller af især "germanske« fortidsminder. I ideologisk henseende var målsætningen den samme; men et personligt modsætningsforhold mellem Himmler og Rosenberg førte til en institutionel kamp, som igen afstedkom et decideret udgravningsvæddeløb og konkurrence om at udplyndre museer og samlinger i Østeuropa. ${ }^{5}$ Alene "Sonderstab Vorgeschichte" hjemførte således ca. 550.000 genstande fra Østeuropa til Tyskland. Navnlig i Ukraine måtte SS-Ahnenerbe og Herbert Jankuhn sande, at »Amt Rosenberg « med dennes chefarkæolog Reinerth var hurtigere. Dernæst måtte Jankuhns Sonderkommando koncentrere sig om Krimhalvøen og Kaukasus, der stod under militær administration. Alligevel kom det også her til en række konkurrerende udgravninger mellem de to institutioner.

\section{Jankuhn og SS-Ahnenerbe}

I Sydslesvig var det SS-Ahnenerbe, der var på hjemmebane. Det skyldtes ikke mindst en god kontakt mellem Herbert Jankuhn og vennen A. Langsdorff, der i august 1935 var blevet Himmlers leder af den arkæologiske forskning. Det lykkedes at forhindre Amt Rosenbergs forsøg på at købe Hedeby-området for næsen af Ahnenerbe. Heinrich Himmler viste ikke mindst Hedeby særlig opmærksomhed, idet han selv besøgte udgravningerne i marts 1937. To år forinden havde han personligt givet ordre til, at Hedeby skulle få status som deutsche »Kulturstätte« med en betydning, der burde jæunføres med 
Pompeji for Italien. ${ }^{6}$ Dermed forhindrede han et planlagt projekt under Joseph Goebbels propagandaministerium, hvis afdeling for Hamborg og Slesvig-Holsten havde planer om at ombygge højborgen ved Hedeby til en nazistisk Thingplads - en slags friluftsteater, hvor man skulle hylde germanerne.

Hedeby-udgravningerne blev prioriteret så højt af Himmler, at de blev den største enkeltpost i Ahnenerbes budget. ${ }^{7}$ Samtidig gjorde Jankuhn karriere, og i 1938 kunne han overtage posten som direktør for det forhistoriske museum i Kiel. På samme tid blev Jankuhn SSSturmbannführer i Himmlers personlige stab. Til gengæld skete der en forskydning i Hedeby-udgravningernes politiske målsætning. Indtil dette tidspunkt havde udgravningerne også haft en antidansk funktion, ${ }^{8}$ nu blev også nordiske forskere inddraget, så projektet blev karakteriseret som et fælles tysk-nordisk udgravningsprojekt. ${ }^{9}$ Det kunne dog ikke forhindre, at Hedeby-udgravningerne blev indstillet ved krigsudbruddet i $1939 .{ }^{10}$ Imidlertid fik Jankuhn selv ny opgaver i SS-regi - bl.a. i Norge og Normandiet. I 1941 blev han professor i Rostock og kom således på endnu større fysisk afstand til Hedeby. Til gengæld øvede han sammen med Wolfram Sievers, der var forretningsfører for Ahnenerbe, afgørende indflydelse på, hvilke arkæologer der blev ansat $i$ universitetsverdenen. ${ }^{11}$ I årene 1941-43 var han undervejs i Ukraine - bl.a. for at finde spor af "Krimgoterne". Her deltog også danskeren Søren Telling på foranledning af direktøren for Kiels arkæologiske museum, Karl Kersten, aktivt i udgravningerne. ${ }^{12}$

\section{Heinrich Himmler og Danevirke}

Den ideologisk betingede interesse for arkæologi skulle også blive Danevirkes redning. Under Anden Verdenskrig 1939-45 blev Danevirke genopdaget i en militær sammenhæng. I 1930erne var flyvestationen Jagel blevet bygget umiddelbart syd for Kovirke. I den forbindelse blev store dele af det østlige Kovirke og Korte Kovirke fjernet. Også Hærvejen blev dækket af beton til de ny start- og landingsbaner. På trods af de omfattende skader, disse anlægsarbejder forvoldte på Danevirke-anlægget, gik det langt fra så galt, som det kunne være gået. ${ }^{13}$ Selveste Heinrich Himmler, der bl.a. var øverste chef for SS og det tyske politi, tog nemlig affære. Den 8.12.1939 skrev Himmler til chefen for det tyske flyvevåben, general Erhard Milch, og meddelte, at der var indgået en detaljeret beretning fra SS-organisationen 


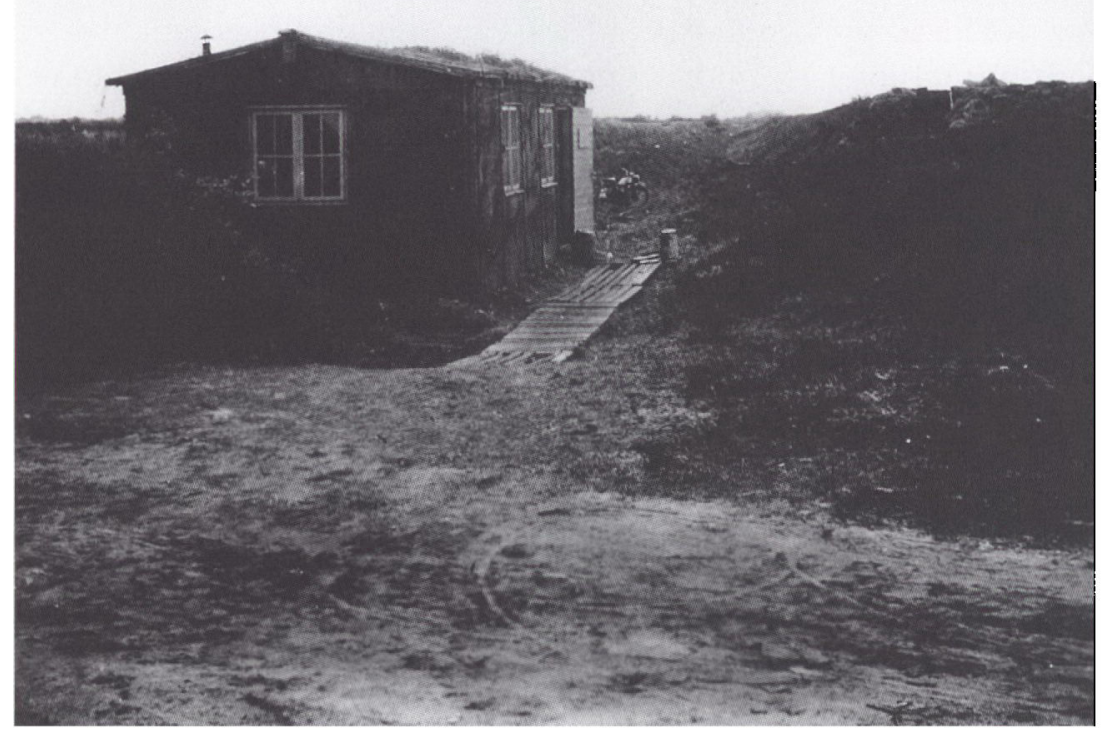

Heinrich Himmler var aktivt involveret $i$ at begranse de militære anlagsarbejder ved Danevirke mest muligt. I 1939 og 1942 bevirkede han, at planlagte afgravininger af Kovirke og Danevirke blev opgivet. Ikke desto mindre blev der rejst militære installationer på volden. Her ses en militærbarak anlagt $i$ graven foran Kovirke (dateret til ca. 980). På selve volden ses en luftvarnsstilling. Foto: Søren Telling, optaget efter krigen $i$ 1945. Kopi findes på Nationalmuseet og Museet ved Danevirke.

"Ahnenerbe" $i$ anledning af de forestående militære byggeaktiviteter bl.a. i Slesvig-Holsten. Her var henved 200 gravhøje truet af tilintetgørelse. Desuden ville udvidelsen af Jagel-flyvepladsen ødelægge det eneste velbevarede stykke af Kovirke, fjerne en del af Hærvejen samt resultere $i$ afgravningen af 400 meter af selve Danevirke samt ødelæggelsen af tre mægtige gravhøje, herunder Danhøjene (tysk:Tvebagen). Himmler bad Milch om at tage hensyn til disse fortidsminder. ${ }^{14}$

Det gjorde flyvergeneralen. Den 29.12.1939 kom hans svar: De af Himmler særligt nævnte fortidsminder ville flyvevåbnet ikke gøre 
krav på. I andre tilfælde skulle der før ødelæggelsen foretages arkæologiske undersøgelser. For Kovirkes vedkommende var der blevet truffet beslutning om at ændre placeringen af startbanen på flyvestation Jagel, så voldanlægget ikke ville blive berørt. Til gengæld måtte en del af Hærvejen ofres. Endelig havde Milch givet ordre om så vidt muligt at skåne fortidsminder $\mathrm{i}$ forbindelse med militære anlægsarbejder. ${ }^{15}$ Således lykkedes det altså Heinrich Himmler på direkte foranledning af "Ahnenerbe" og Kiels arkæologiske museum at redde Danevirke fra omfattende tilintetgørelser.

Senere i krigen skulle SS atter få lejlighed til at gribe ind til fordel for Danevirke. I 1942 blev Jagel flyveplads udvidet igen. Også denne gang var der lagt planer, der ville have resulteret i fjernelsen af store dele af Kovirke og Danhøjene. I oktober 1942 blev det meddelt direktøren for det arkæologiske museum i Kiel, Gustav Schwantes, at der nu skulle bygges en ny startbane, og at det $i$ denne forbindelse ville være påkrævet at fjerne ca. $300 \mathrm{~m}$ af Kovirke samt Danhøjene og yderligere en gravhøj ved volden. Schwantes gik omgående $\mathbf{i}$ aktion og henvendte sig 24.10.1942 til »Luftgaukommando XI«i Hamborg med en redegørelse for sagen og en opfordring til at ændre planerne. Den 26.10.1942 fulgte Schwantes op med endnu et brev til en anden militær myndighed i Hamborg. Heri manede han til at skåne fortidsminderne, idet de ikke mindst var en hjertesag for Slesvig-Holsten og Danmark, men også for Tyskland og den historisk interesserede verden i øvrigt. ${ }^{16}$

På samme tid foranledigede Schwantes, at der blev rettet en direkte henvendelse til Heinrich Himmler via "Landeshauptmann der Provinz Schleswig-Holstein “, dr. Schaupt. Også Ahnenerbe var nu blevet indblandet $i$ sagen og skrev et udkast til Himmler, som blev bedt om at tage kontakt til general Milch igen. Denne gang blev der bl.a. argumenteret med, at man $\mathrm{i}$ Italien aldrig ville handle på en tilsvarende måde og tilintetgøre fortidsminder. Himmler godkendte konceptet og sendte det 11.11.1942 til general Milch. Inden da var Himmler blevet kontaktet af landråden i Slesvig, Kolbe, der 2.11.1942 bad om Himmlers indgriben. Samtidig havde Kolbe henvendt sig til flyvergeneralen Wolf i Hamborg med et brev, hvori han betegnede planerne som en barbarisk handling, der ville volde skade og kunne misbruges til antitysk propaganda i Danmark og af de allierede. Desuden understregede han, at Danevirke selv for den jævneste bonde var en helligdom. ${ }^{17}$ 


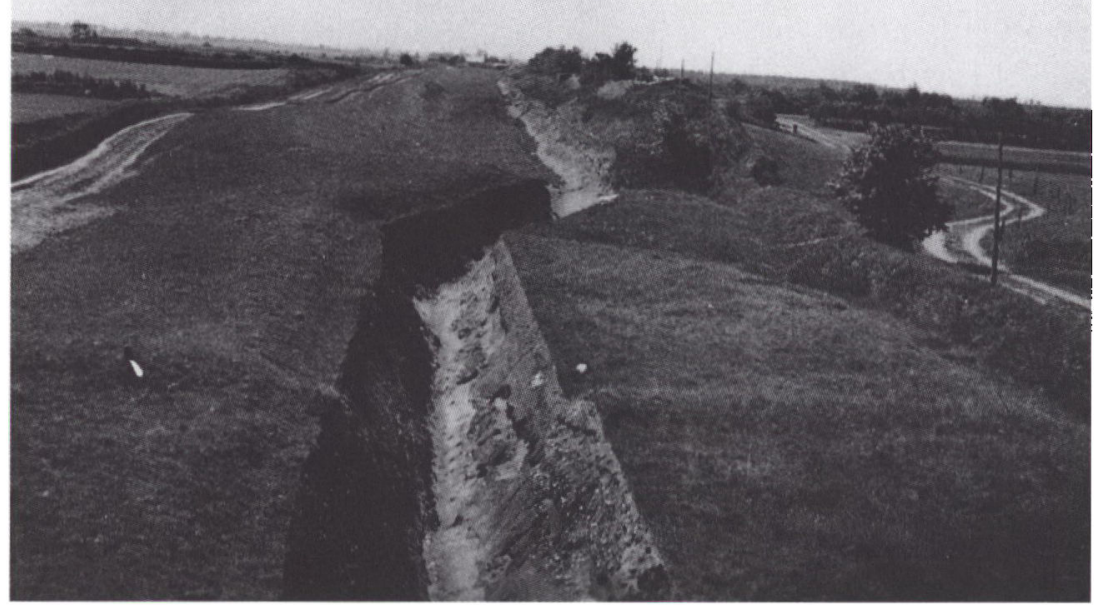

I november 1944 blev der anlagt en pansergrav ved Danevirke. Det var oprindeligt hensigten at anlægge graven på dét sted, hvor resterne af den middelalderlige Valdemarsmur befinder sig inde $i$ jordvolden. Det ville have resulteret $i$ tilintetgarelsen af fortidsmindet. Ikke mindst takket være Soren Tellings engagement blev planerne dog ændret, og graven anlagt foran selve muren. Ikke desto mindre var der tale om et omfattende indgreb i Danevirke. Foto: Søren Telling, optaget efter krigen i 1945. Kopi findes på Nationalmuseet og Museet ved Danevirke.

Denne henvendelse satte gang i sagen. Den 6.11.1942 rejste general Wolf til Slesvig - de oprindelige planer blev opgivet, og Kovirke reddet endnu engang. Dette kunne landråd Kolbe meddele dagen efter til Himmler. Også fra general Milchs side fik Himmler den 12.11.1942 bekræftet, at planerne var opgivet. Der var således fundet en løsning, der tilfredsstillede Himmler, som i et svarbrev til Milch 24.11.1942 fastslog: "Ich freue mich, daß die wertvollen Anlagen erhalten blei- 
ben «. ${ }^{18}$ Herefter skulle Kovirke ikke længere blive truet af udbygningsplaner på flyvestation Jagel.

\section{Søren Telling: »Danmarks vagthund«}

Selv om museet i Kiel med sin henvendelse til de militære myndigheder i 1942 havde bidraget til at forhindre en sløjfning af Kovirke og de to Danhøje, kunne museumsfolkene intet stille op imod en militær brug af fortidsminderne. Kovirke blev udbygget med kanonstandpladser og latrinhuse, men også med barakker og skure. Ikke desto mindre blev volden i sig selv ikke fjernet, til trods for mange beskadigelser.

I 1944 så det imidlertid ud, som om det nu skulle være selve Danevirkes hovedvold, der måtte lide overlast. Her skulle der i november 1944 etableres en pansergrav. Det var hensigten, at den skulle placeres på samme sted, hvor resterne af Valdemarsmuren befandt sig. Det ville have medført fjernelsen af de nogle steder betydelige murrester og dermed reelt ødelæggelsen af det egentlige Danevirke. Danskeren Søren Telling, der var tilknyttet museumsmyndighederne i Kiel, tog affære. ${ }^{19}$

Søren Telling var en sammensat person, glødende dansk nationalist, som i en periode havde været dybt involveret i det danske nazistpartis aktiviteter. Han blev født i 1895 i Randers som Søren Christian Christensen Telling, men blev frem til 1919 kaldt Christian. Hans far var dengang musikdirektør i Randers og hed Søren Telling. ${ }^{20}$ Under Første Verdenskrig var han korporal. I 1920-21 var han frivillig som løjtnant i det danske kompagni Westenholtz, der deltog i Estlands løsrivelseskamp fra Rusland. Det blev han udmærket for med det estiske frihedskors. Siden var han skovarbejder i Estland og dernæst musiker og tømrermester i København. I marts 1935 blev han medlem af Frits Clausens danske nazistparti DNSAP.

I sine efterrationaliserende erindringer, der foreligger som manuskript $\mathrm{i}$ hans arkiv, skriver Telling om medlemskabet: "Jeg havde aldrig interesseret mig for Politik för. Jeg ansaa Politik for noget Svindel. Jeg skulle ikke have fraveget denne Opfattelse. Jeg gik til bemeldte Möde og oplevede noget, som ikke för var set $\mathrm{i}$ min Tilvärelse. Jeg lod mig indfange af det store Opbud af Faner, Militärmusik og Parademarcher i det festligt smykkede Rum. Talerne profeterede Genoprettelse af Härens Anseelse og Genrejsning af Danmarks Forsvar. 
Er det underligt, at saadanne Toner virkede paa mig, der er Efterkommer af Krigere i mange Led, og som selv med Sorg havde fulgt Nedbrydningen af den danske Här og Bolchiviseringen af alle Forhold? Jeg meldte mig ind i DNSAP samme Aften “. ${ }^{21}$

Telling blev herefter en engageret og begejstret dansk nazist, der foruden at være medlem i Clausens personlige stab også var leder af SA's musikkorps. Han havde således et nært forhold til Frits Clausen og gjorde et stort nummer ud af dennes fødselsdag. Således vækkede Telling på denne dag hele Bovrup, hvor Clausen boede, med pauke og trompet, da han - iført en selvbestaltet sort uniform og hvide handsker - kom ridende ind i landsbyen på sin hest Rosinante og med sin bedstefars sølvtrompet, der havde været $\mathrm{i}$ kamp på Dybbøl Banke i $1864 .^{22}$

Søren Telling spillede en overgang også en vigtig rolle ved forberedelsen af DNSAPs landsstævne på Koldinghus i Kolding i 1939. ${ }^{23}$ Han nærede en glødende begejstring for oldtiden. Han kom jævnligt på Nationalmuseet, og under disse besøg fostrede han tanken om at inddrage oldtidsfundene i den nazistiske agitation. I august 1938 søgte han derfor om - og fik - tilladelse til at blæse i museets bronzealder-lurer til »musikvidenskabelige studier «. ${ }^{24}$ Det var daværende museumsinspektør Johannes Brøndsted, som siden formelt gav tilladelsen. ${ }^{25}$ Dernæst troppede Telling jævnligt op med en flok venner og blæste lur i efteråret 1938. Hans engagement afsluttedes imidlertid brat, da han med kort varsel og af uklare årsager rejste til Tyskland. Han forlod Kobenhavn og slog sig ned i Kiel.

Omkring denne tid findes der flere, indbyrdes modstridende versioner: Telling selv skriver i sit erindringsmanuskript, at han i efteråret 1938 fik tilbudt en stilling i Kiels arkæologiske museum af dettes direktør Karl Kersten, som han havde lært at kende i forbindelse med lurblæsningen på Nationalmuseet. Telling oplyser at være rejst i november 1938 - og "Ved min Afrejse - eller lige efter udmeldte jeg mig af DNSAP for ikke siden at indtræde i nogetsomhelst politisk Virke ${ }^{26}$ Imidlertid synes Telling at have husket forkert på flere punkter:

I en redegørelse for sin færden siden 1939, som Søren Telling den 6.2.1946 tilsendte Dansk Generalsekretariat i Flensborg skriver han nemlig, at han 9.1.1939 rejste til Kiel: "Aarsag til Rejsen var Ønske om at komme ud af det politiske Vrøvl og Væsen, som jeg havde været inde $i$ fra 1935 i D.N.S.A.P. samt at prøve paa at danne mig en Livsstilling som Erstatning for min af Politik ødelagte og forsømte 
Existens i Danmark «. ${ }^{27}$ Telling tilføjer, at han i marts/april 1939 søgte om tysk statsborgerskab. Samtidig noterer han, at han forventede, at denne ansøgning først ville blive behandlet og endelig afgjort efter krigen. Det var naturligvis en efterrationalisering, idet der i foråret 1939 endnu ikke var udsigt til nogen krig. To år senere, den 7.7.1941, modtog Telling så det tyske borgerbrev - og dermed mistede han og hans familie det danske statsborgerskab.

Ifølge undersøgelser, som Sydslesvigsk Forenings daværende generalsekretær Frants Thygesen foretog efter krigen, var Telling først udtrådt af DNSAP i foråret 1940, før Danmarks besættelse 9. april. Denne oplysning modsiges dog af Rigspolitiet, der gennemgik Bovrupkartoteket over medlemmerne i DNSAP. Heri oplyses om Søren Telling, at han blev medlem af nazistpartiet 1.3.1935 med medlemsnummeret 10.174 og først blev slettet af medlemslisten den 16.7.1941 altså 9 dage efter, at Telling var blevet tysk statsborger. ${ }^{28}$ Det er også en sandhed med modifikationer, at Telling tog afstand fra nazismen ved sin udrejse fra Danmark i 1939. Faktisk skriver han selv i sin levnedsskildring af 6.2.1946, at han i 1941 på »forventning « indgav andragende om optagelse $\mathrm{i}$ NSDAP, men at denne ansøgning aldrig resulterede i noget partimedlemskab. ${ }^{29}$ I stedet begyndte han at lægge afstand til nazismen. ${ }^{30}$

Med henblik på Tellings ansættelse ved Kiels arkæologiske museum giver levnedsmiddelrationeringskortet fra efter krigen, der er bevaret $\mathrm{i}$ hans personlige arkiv, også en langt senere dato. ${ }^{31}$ Ifølge attesten på kortet fra arbejdsgiverens side havde Telling først fundet ansættelse den 1.7.1940 - over halvandet år senere, end Telling selv hævder $\mathbf{i}$ forskellige sammenhænge. Imidlertid vidste Telling godt selv, hvordan sagen hang sammen. I sin livsredegørelse over for Dansk Generalsekretariat 6.2.1946 meddeler han nemlig, at han i tiden januar 1939 til juni 1940 havde været ansat som korttegner ved vejvæsenet. Først den 1.7.1940 tiltrådte han en stilling som teknisk assistent ved Kieler museets afdeling for landopmåling. Her var han fastansat frem til 31.8.1945. ${ }^{32}$ For at gøre hele sagen endnu mere uigennemskuelig erklærede direktøren for Landesamt für Vorgeschichte og Kiels Museum, Karl Kersten, under ed 18.1.1948, at han havde lært Telling at kende i København efteråret 1938, og at denne i 1939 tiltrådte som assistent ved Landesamt für Vorgeschichte. ${ }^{33}$ Sidst i krigen var Telling med til at evakuere oldtidsmuseet $i$ Kiel og viede som sagt Danevirke sin store personlige indsats. Det var især runeste- 
nene, han var med til at redde, få dage for museets bygning blev bombet. Dem fik Telling nedgravet $i$ de ældgamle hærvejsspor ved Fockbeck i nærheden af Rendsborg, så de ubeskadiget kunne overstå krigen. ${ }^{34}$

I en række æreserklæringer, der foreligger i Tellings arkiv i form af kopier af beedigede erklæringer og personlige breve, fremhæves det, at Telling havde taget grundigt afsked med nazismen i 1941, senest i 1943. I en erklæring af 1.6.1946 skriver således Karl Kersten, at Telling i oktober 1943 var blevet arresteret af Gestapo på Sild grundet nedladende offentlige ytringer vendt imod både nazistpartiet og værnemagten: "Die deutsche Wehrmacht habe sich der schwersten Kulturbarbarei schuldig gemacht, obwohl sie ebenso wie die NSDAP sich als deren Schützer ausgäbe; er Telling fühle sich als Däne aber im besonderem Maße als Schützer insbesondere des Dannewerks «. ${ }^{35}$

I den førnævnte erklæring afgivet af Karl Kersten 18.1.1948 fastslår denne bl.a., at Telling aldrig havde været aktiv for DNSAP eller NSDAP i årene 1939-45, men udelukkende havde gjort sit arbejde. Han fortsætter: "Nachdem er im Jahre 1941 Gelegenheit gehabt hatte, Einsicht in die Tàtigkeit der NSDAP zu nehmen, liess sich bei ihm ganz ein krasser Wechsel seiner seitherigen Einstellung beobachten, seit dem Jahre 1941 wurde Herr Telling einer der schärfsten Gegner der NSDAP, die mir in meinem Leben überhaupt bekannt geworden sind «. Dette bragte Telling i stor fare, da hans åbne kritik resulterede i arrestation på Sild. Og Kersten konkluderer: "Wenn gegen Telling der Vorwurf seiner freundlichen frühen Einstellung gegenüber der NSDAP erhoben wird, steht dem als sachliche Leistung während des Krieges die Rettung kultureller und historischer Werke gegenüber, die für die Geschichte Dänemarks und Schleswig-Holsteins von der grössten Bedeutung sind. Die Rettung des Danewerks und der südlichsten Runensteine des Nordens wird mit dem Namen Tellings untrennbar verbunden bleiben! $\alpha^{36}$

Telling synes i det mindste efter 1941 ikke længere at have været nazist. Det var ganske vist noget senere, end han selv hævdede - men alligevel kunne hans sindelag bevidnes. Naturligvis kunne der stilles det spørgsmål, hvorvidt disse erklæringer blev afgivet af folk, der selv havde en interesse $i$ at fremstå som uhildede. Skal disse erklæringer tages for pålydende? Skal de ikke snarest ses i en ganske anden kontekst: Renser Kersten - og i mindre grad Schwantes ${ }^{37}$ - med disse udsagn ikke samtidig sig selv? Disse og andre spørgsmål kan og må 
rejses; men det ligger uden for nærværende artikels rammer at give et endegyldigt svar. Det skal blot bemærkes, at Karl Kersten i 1944 blev udnævnt til arkæologisk sagkyndig for de tyske besættelsestropper i Danmark, ${ }^{38}$ og at han i 1957 blev slået til ridder af Dannebrog. ${ }^{39}$

Sådanne positive vidnesbyrd blev der brug for, idet Tellings forhold til nazismen blev bragt på banen ved forskellige lejligheder. Det skete bl.a. i foråret 1955, da en dansk landbrugskonsulent i Slesvig havde bebrejdet Hjemmeværnet, at dette benyttede sig af »den gamle nazist« Telling som guide på voldene. Hjemmeværnet rettede derpå en forespørgsel til Sydslesvigsk Forening. Sydslesvigsk Forenings daværende generalsekretær Frants Thygesen svarede i et brev af 4.4.1955 til hjemmeværnskaptajnen E. F. S. Knudsen, at Tellings forhold var blevet undersøgt nøje efter $1945 .{ }^{40}$ Man var klar over hans fortid, men at han havde meldt sig ud i 1940 og samme år havde sendt sine børn i dansk skole i Slesvig hos distriktsskoleinspektor Svend Johannsen. Medlemskabet i DNSAP betød imidlertid, at Telling ikke kunne optages i SSF før i 1949, da foreningen begyndte at optage "ikke ondartede« tidligere medlemmer af nazistpartiet. Imidlertid glemmer hhv. var SSF ikke klar over, at Telling faktisk en overgang helt tilbage i 1945 af skoleleder cand. theol. og tidligere kz-fange Svend Johannsen var blevet ansat som sekretær for og leder af Slesvigsk Forenings sekretariat i Slesvig. ${ }^{41}$ Til gengæld havde Telling - ifølge Thygesen gjort sig store fortjenester:

"Under alle omstændigheder ville det være ganske urimeligt at slå med sten nu 10 år efter kapitulationen og 15 år efter Tellings udtræden af nazipartiet. Han har begået en fejl for ca. 20 år siden, men ingen forbrydelse, og den fejl opvejes efter vort skøn af hans fortjenester siden da «. ${ }^{42}$ Så kunne Hjemmeværnet fortsat med god samvittighed benytte sig af Telling som guide.

Denne vurdering af Tellings forhold til nazismen går igen i en række andre vidnesbyrd, som alle understreger skiftet omkring år 1941. Efter udgravningsopholdet i Ukraine maj-oktober 1943 blev denne nazi-kritiske holdning yderligere forstærket. Den kendte journalist på Flensborg Avis, Tage Jessen, skrev således i en erklæring af 7.2.1946, at efter rejsen til Ukraine havde Telling definitivt »brudt med alt, hvad der hedder Nazismen, idet han havde set for meget af dens sande Væsen « ${ }^{43}$ Følgelig havde Telling senest taget afstand fra nazismen i 1943.

Alligevel betød Tellings tidligere medlemskab af DNSAP, at han 
ikke kunne få sit danske statsborgerskab tilbage igen, da han søgte derom i 1960. Her vejede tiden før 1941 tungere end Tellings indsats for Danevirke fra 1944. Han blev ganske vist støttet i sit andragende af fremtrædende danskere, bl.a. Nationalmuseets direktør Johannes Brøndsted, der 13.7.1960 i et brev skriver: "Søren Telling har i en aarrække været Danmarks vagthund paa Danevirke «. ${ }^{44}$ Samtidig understregede Brøndsted, at der bør dispenseres for krav om bopæl i Danmark, idet Tellings tilsyn med voldene er uvurderlig. Til trods for denne og tilsvarende anbefalinger fra fremtrædende danskere afviste Folketingets indfødsretsudvalg med et snævert flertal ansøgningen. Det var fortiden, der spøgede. ${ }^{45}$

Der var intet at gøre. Telling var skuffet. Tilmed havde han siden 1.9.1945 været uden fast stilling. Han var ulønnet tilsynsførende med Danevirke, men kunne ikke leve af sin idealisme. I stedet måtte han leve af privat støtte fra Danmark.

\section{Danevirkes redningsmand?}

Ansættelsen ved Kiels arkæologiske Museeum førte til, at Telling blev aktivt involveret $i$ redningen af Danevirke under krigen. Det skete $i$ forbindelse med planerne i efteråret 1944 om etablering af en pansergrav ved hovedvolden, hvor resterne af Valdemarsmuren ligger. Ifølge egne oplysninger tog han den 28.10.1944 telefonisk kontakt til Himmlers adjudant for Ahnenerbeafdelingen, Wolfram Sievers, og fik denne i en timelang samtale sent på aftenen overbevist om, at arbejdet skulle indskrænkes mest muligt.

Telling meddeler i sine egne optegnelser, at han fik ordre til »efter eget Skøn at gribe ind overfor ethvert Indgreb i Danevirkevolden, der kunde medføre, at den blev uanvendelig som arkæologisk Forskningsobject. De er personlig ansvarlig for, at der protesteres i rette Tid «.

Men, meddeler Telling: „De maa klare Dem uden papirlige Beviser paa Deres Opgave, indtil vort Telegram, der afgaar nu, indtræffer. Men det kan vare flere Dage, da alt er bombet her. Slut « ${ }^{46}$

Telling modtog - efter egne udsagn - nogle dage senere et telegram, der gav ham myndighed til at forhindre, at volden skulle lide overlast. Telegrammet er dateret den 2.11.1944. ${ }^{47}$ Det meddeler, at Heinrich Himmler havde beordret, at fortidsminder også under de foreliggende omstændigheder så vidt muligt skal skånes i forbindelse 


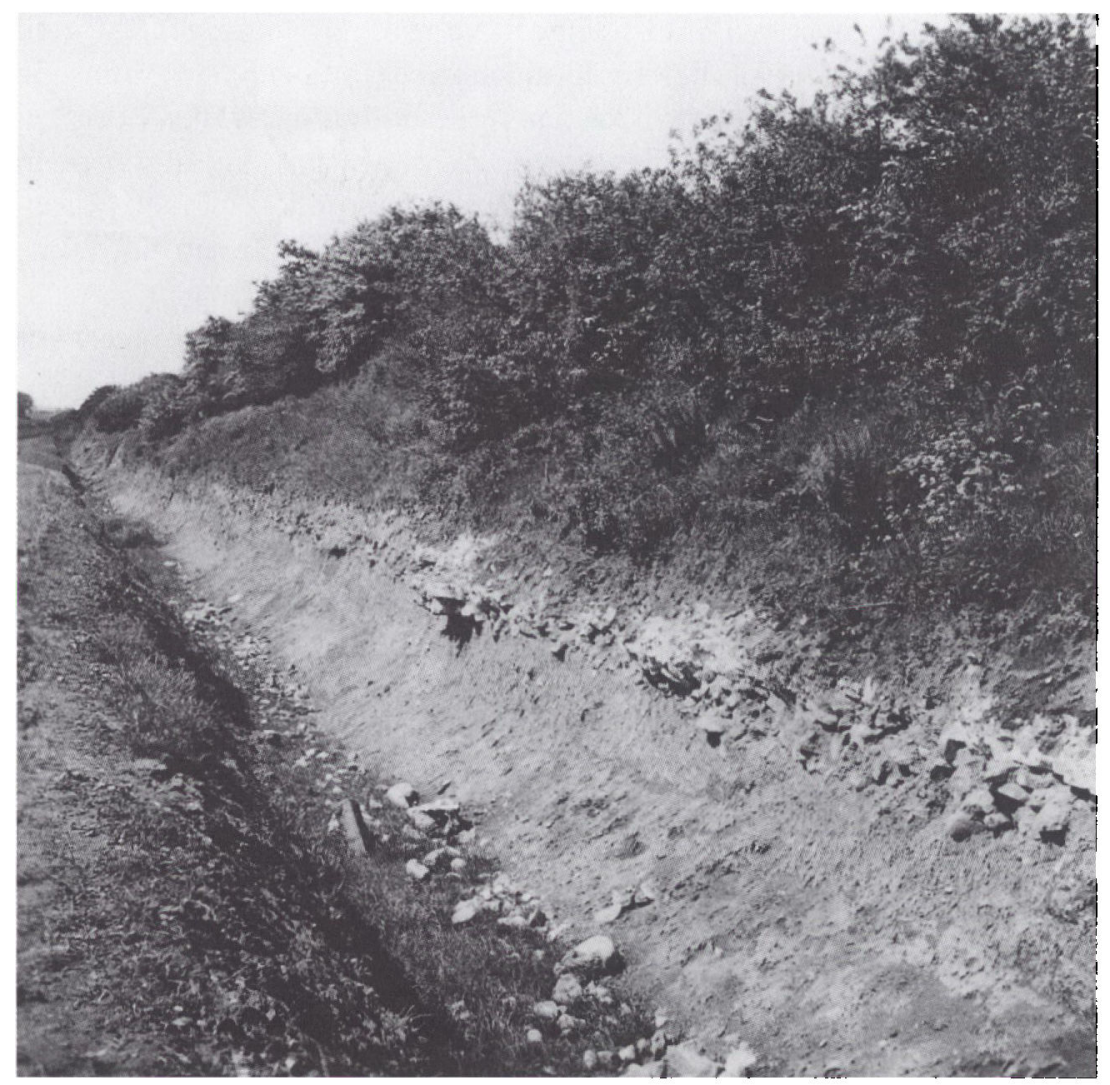

Pansergraven ved Danevirke blev på centrale strækninger anlagt umiddelbart foran de bevarede rester af Valdemarsmuren (ca. 1165-90) hhv. Kampestensmuren (ca. 737750). Det forte til dels til nedstyrtninger af murbrokker $i$ tankfælden. Foto: Søren Telling, optaget efter krigen $i$ 1945. Kopi findes på Nationalmuseet og Museet ved Danevirke.

med befæstningsarbejder, og at fund, der gøres i denne sammenhæng, skal bjærges. Telling beordres endelig til at foretage de nødvendige skridt. Med telegrammet $i$ hånden fik han standset pansergravsarbejderne. De ankom netop 2. november, som han senere samme dag passende modtog telegrammet. Det vides i øvrigt ikke, om telegrammet vitterligt stammede fra SS-førerens kontor, eller om Telling havde fingeret det. Det kendes kun fra Søren Tellings arkiv - altså i modtagerform. Pansergraverne syntes at have været meget skeptiske over for Tellings mundtlige meddelelse om kompetence fra selveste 
Himmler - og derfor ville et telegram være til stor nytte for at give ordene autoritet. Det kan ikke udelukkes, at Telling selv konstruerede telegrammet - men det gør ikke hans personlige indsats mindre bemærkelsesværdig. Under alle omstændigheder gav Tellings optrin virkning. Planerne blev omgående ændret - men ikke opgivet. Valdemarsmuren fik lov til at blive stående, men pansergraven blev ikke desto mindre etableret langs med Hovedvolden.

Danevirke blev således ikke ødelagt, men alligevel beskadiget. Pansergraven blev anlagt foran murresterne. Arbejdet blev i tiden 5.12.11.1944 gennemført af - ifølge Tellings oplysninger -9.000 arbejdere og 400 partifunktionærer. ${ }^{48}$ Det kunne være gået langt værre. $\mathrm{Nu}$ blev der gravet en dyb grav, der ganske vist skæmmede voldens ydre, men trods beskadigelser alligevel ikke ødelagde centrale dele af den. Da pansergraven var færdiggjort, ankom den 16.1.1945 en general Knochenhauer fra Hamborg og fastslog efter kort besigtigelse, at graven skulle have været anlagt $5 \mathrm{~km}$ længere nordpå, såfremt den skulle have haft den mindste betydning. Hans konklusion var, at pansergraven kun kunne "tjene til at ærgre og fortrædige vor venligsindede Nabo i Nord, saa jeg anbefaler Dem, at De skyndsomst dækker det hele til igen - inden altfor tydelig Forargelse opstaar «. ${ }^{49}$

Som fremhævet er Telling den eneste kilde. I arkiverne vedrørende SS, Ahnenerbe og Kieler-museet findes derimod andre, supplerende oplysninger omkring Danevirke-redningen. Heri fremgår nemlig af en rapport forfattet af Kiel-museets fungerende leder Gustav Schwantes 29.11.1944, at denne glædede sig over, at det takket være Himmlers personlige indgriben havde været muligt at betro museumsdirektøren Karl Kersten tilsynet med de arkæologiske arbejder ved Danevirke. ${ }^{50}$ Det oplyses endvidere, at Kersten sammen med Telling ved hjælp af 9.000 mand forsøgte at begrænse skaden på Danevirke mest muligt. ${ }^{51}$ Arbejdsstyrken på 9.000 mand er forbløffende identisk med den styrke, som Telling kæmpede imod måneden forinden. Noget kunne tyde på, at der mellem forskellige forhold er sket en sammenblanding, der ikke umiddelbart kan klarlægges. Tellings version er imidlertid efterhånden blevet gentaget så mange gange ikke mindst i avisartikler $i$ en lang række danske dagblade $i$ forbindelse med Tellings 70 års fødselsdag i marts 1965, at historien er blevet hver mands eje. ${ }^{52}$ Bekræftes eller afkræftes kan den ikke.

Mere interessant er, at der i Ahnenerbes arkiver findes bevarede telegrammer fra tiden 4. og 5.11.1944 samt 9.12.1944; men ingen af 


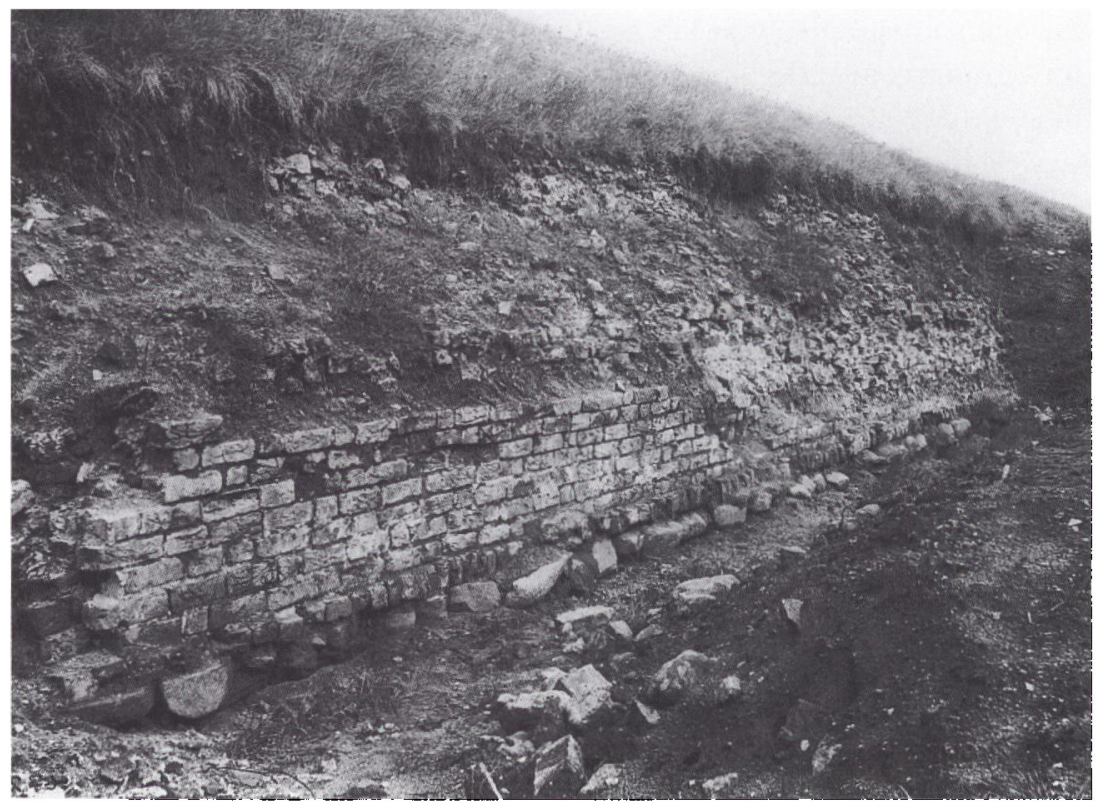

Pansergraven kan på sin vis betegnes som én stor udgravning på langs. Efter krigen kunne danske arkæologer undersage volden og Valdemarsmuren. Her ses et ganske velbevaret stykke af teglstensmuren, hoor den ydre skalmur er delvist bevaret, og hoor fundamentet af kampesten fremstär tydeligt $i$ udgravningen. Foto: C. G. Schultz 1946, Nationalmuseet.

dem er adresseret til Telling. ${ }^{53}$ Telegramkorrespondancen foregik derimod mellem Schwantes og Sievers. Desuden blev der 9.12.1945 udstedt et legitimationskort til Kersten. Der findes i netop denne kontekst ingen genpart af det famøse Telling-telegram. En del tyder altså på, at telegrammet kunne være et falsum, konstrueret af Telling for at standse pansergravningerne. For det er lige så klart, at Telling var til stede på Danevirke i disse dage, og at han vitterligt fik mindsket ødelæggelserne. Man har derfor grund til at forestille sig, at Telling med et formentlig »hjemmelavet« telegram i hånden fik standset arbejdet.

I Tellings personlige arkiv findes - foruden hans egne optegnelser og fortællinger, som blev videregivet $i$ en lang række avisartikler spredte oplysninger omkring etableringen af pansergraven. Det er især $\mathrm{i}$ breve og erklæringer fra de to tidligere direktører for Kieler museet, Karl Kersten og Gustav Schwantes, at emnet berøres. Karl Kersten skrev $i$ et vidnesbyrd udstedt til Søren Telling 12.9.1945, den 
dag hans ansættelse ved landsmuseet og de arkæologiske myndigheder ophørte, at Telling måtte takkes for, at Kiel-museets samlinger blev reddet, før bygningen blev bombet. Om pansergravsbyggeriet, skriver Kersten: »unter den größten Schwierigkeiten und starken persönlichen Anfeindungen gelang es Herrn Telling jedenfalls das am besten erhaltene Stück des Danewerks beim Rothen Krug vor der Verstümmelung $\mathbf{z u}$ bewahren . $^{\mathbf{5 4}}$

Mere uddybende erklærede Karl Kersten den 18.1.1948 om Søren Tellings forhold til nazismen i forbindelse med pansergravsbyggeriet i november 1944: "Nur dem sehr energischen Einschreiten von Telling ist es zu verdanken, dass das Dannewerk nicht gänzlich vernichtet wurde ${ }^{55}$ Dette synes at bekræfte en del af Tellings egen version dog med det forbehold, at Kersten taler $\mathrm{i}$ almene vendinger, der lige så godt kan betyde, at Telling gjorde opmærksom på, hvad der var i gære, og dernæst pressede på over for museet for at sætte noget $i$ gang for at afværge ødelæggelsen.

Gustav Schwantes skrev til Telling den selvsamme 12.9.1945: »Noch beträchtlich weiter ging Ihr Einsatz, als es galt, das Dannewerk vor der Zerstörung durch Militärbauten zu bewahren. Diese zerstörenden Arbeiten ganz abzuwenden, gelang freilich niemanden von uns, da eine Armee von 9000 Arbeitern und hunderten von Partei-Funktionären der NSDAP bereits in Bewegung gesetzt worden waren, bevor wir überhaupt etwas von dem Plan vernahmen. Dann haben Sie aber während der Arbeiten alles getan, um das Unheil zu mindern, z.T. mit grossem Erfolg. So verdanken wir Ihnen, dass der Panzergraben an besterhaltenen Stellen des Dannewerks auf eine leider nur allzu kurze Strecke in gewisser Entfernung vor dem Denkmal geführt wurde und andere Erfolge «. ${ }^{56}$

Historien om Himmler/Sievers-telegrammet nævnes slet ikke. Er historien sandfærdig, inklusive telegrammets ægthed? Eller var telegrammet et dristigt falsum? Noget endeligt svar kan trods alle kildegranskninger ikke gives. I Sydslesvigsk Forenings arkiv findes i mappen over personsager også en fyldig samling dokumenter om Søren Telling. I en særdeles nøgtern redegørelse for sin færden siden indrejsen til Tyskland i 1939 skriver han selv den 6.2 .1946 bl.a. om begivenhederne i efteråret 1944: "Jeg virkede med alle tilladte og ikke tilladte Midler for at afvende den forfærdelige Ødelæggelse, der var i Anmarch overfor det storslåede Danske Mindesmærke ... Det lykkedes mig paa store Strækninger af den $3 \mathrm{Km}$ lange Ødelæggelsesfront 


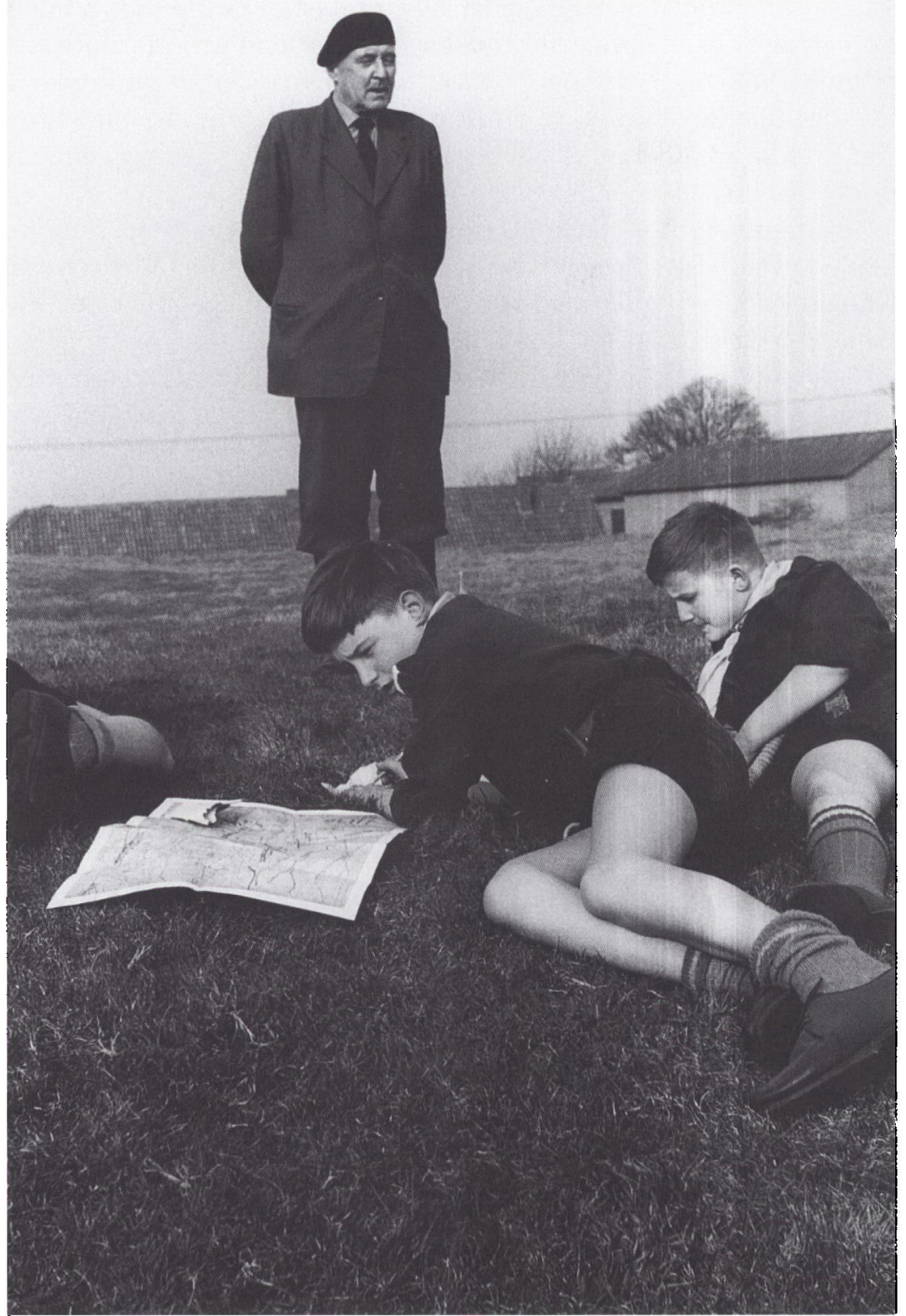

Fra 1945 til sin død $i$ juli 1968 boede Søren Telling permanent på Danevirke $i$ en tidligere tysk militxrbarak på selve Hovedvoldens nordside. Her instruerer han en flok sydslesvigske spejdere i Danevirkes historie. Foto: Torben Kvist, ca. 1963. Kopi findes på Museet ved Danevirke. 
at faa Volden fuldstændig skaanet, og paa Resten af Strækningen hidførte mine meget farlige Bestræbelser et væsentligt skaansommere Indgreb i Voldens Sydfront «. ${ }^{57}$ Måske dækker de særligt understregede "ikke tilladte " midler over netop et falsk telegram, der blev brugt som middel til at standse ødelæggelserne? Det øvrige begivenhedsforløb står dog til troende.

Pansergraven blev etableret; men Tellings væsentligste fortjeneste i denne forbindelse synes at have været, at han fik sikret, at Hovedvolden ved Rødekro og dermed ved det nuværende museum Danevirkegården blev skånet. Alt $\mathrm{i}$ alt må det således skønnes, at Søren Telling har "pyntet« på fortællingen, men ikke desto mindre aktivt har medvirket på Danevirke-volden i bestræbelserne på så vidt muligt at sikre fortidsmindet mod ødelæggelserne. Det lykkedes ikke helt. Det kom til ødelæggelser, og dele af Valdemarsmuren blev på strækninger undermineret eller helt revet ned. Andre steder blev der gravet helt ind til Kampestensmuren, som stedlige bønder dernæst til dels benyttede sig af som stenbrud i vinteren 1944-45. Men det kunne alt sammen være gået langt værre. Søren Tellings indsats har således været af central betydning. Det skete utvivlsomt med stor fare for arrestation.

Pansergraven var ubrugelig. Men den blev ikke dækket til igen. Hele den følgende vinter stod graven åben, og betragtelige dele af volden bagved begyndte at vælte ned $i$ den. Volden var ved at gå i forfald. Heinrich Himmler gav i begyndelsen af februar 1945 ordre om, at volden skulle repareres, men det skete ikke. Således var bl.a. højtstående slesvig-holstenske nazister imod. Efter befrielsen lykkedes det heller ikke at få overbevist den britiske militærguvernør om at sikre Danevirke. Samtidig fortsatte nedstyrtningerne og rovdriften på volden.

I sidste ende var det endnu engang Søren Telling, der i god forståelse med museumsmyndighederne satte gang i reparationerne.$^{58}$ Den 16.11.1945 sendte han simpelthen et ultimatum til myndighederne og annoncerede, at han den 26.11.1945 ville iværksætte reparationsarbejderne, såfremt der forinden ikke var blevet truffet nogen anden afgørelse. Denne skrivelse satte fart i myndighederne, der allerede den 23.11.1945 indhentede tilbud vedrørende arbejderne hos et lokalt firma i Slesvig. Derpå gik reparationsarbejdet vitterligt i gang den 26.11.1945 kl. 8.00 om morgenen med en tilfreds Søren Telling til stede. Jordarbejderne tog dog sin tid, og der skulle gå et helt år, før graven var helt tildækket, og græsset kunne begynde at gro på de 
reparerede skrænter. Danevirke var blevet sat delvist i stand igen; men volden var endnu ikke endeligt sikret.

\section{På vej til fredningen $i$ august 1950}

Danevirke havde lidt overlast ved krigens slutning og umiddelbart derefter. De lokale bønder brugte volden til kreatur- og hestegræsning, andre gravede jord væk, mens atter andre begyndte at bruge volden til gruskørsel. Østtyske flygtninge bosatte sig ved volden og påførte den ødelæggelser. Lokale beboere fortæller desuden, at det var populært at kradse kalken, der binder stenene i Valdemarsmuren, bort for at bruge den som hønsefoder. Selve stenene blev også brugt, da de indgik i opførelsen af svinestier og hønsehuse. Endelig hobede skrald og affald sig op langs med og til dels på voldanlægget. Alt dette kunne ske, fordi Danevirke ikke var totalfredet. Søren Telling førte imidlertid et lidenskabeligt tilsyn med voldene og indgav politianmeldelse for ethvert indgreb $\mathrm{i}$ de bestående fortidsminder.

I de første år havde Telling hjemmel til disse aktioner. Den 30.9.1946 bemyndigede Kreis Schleswig ham til at føre tilsyn med hele Danevirke. ${ }^{59}$ I samme ombæring fik han stillet en barak fra 1941 til rådighed som bolig. Denne tilladelse blev imidlertid ophævet 9.3.1950, da man ikke længere havde brug for hans medvirken - og derefter havde Telling ingen myndighed til at agere, som han gjorde. ${ }^{60}$ Det ændrede dog intet ved Tellings opfattelse af og syn på sit ansvar for voldanlægget.

Allerede i krigens sidste dage var Telling blevet udstyret med et særligt "Ausweis", der skulle gøre det muligt for ham at gribe ind, når der var fare for, at fortidsminder ville lide overlast. Gustav Schwantes udstedte således 2.5.1945 et legitimationspapir, der fastslog, at Søren Telling havde til opgave at redde uerstattelig nordtysk kulturarv fra ødelæggelse, især i tilfælde af, at fremmede styrker skulle besætte landet. ${ }^{61}$ Derfor skulle Telling kunne færdes frit og uhindret.

Telling tog denne opgave særdeles alvorligt og varetog den også i den første tid efter kapitulationen. I denne forbindelse tog Telling egenhændigt sit gamle danske pas $\mathrm{i}$ brug, der åbnede døre og gav tilladelser fra de britiske militærmyndigheder. Således kom Telling i besiddelse af et "Registration Card « for »Non-Germans«, der dog på bagsiden også havde det tyske legitimationspapir »Ausweis« udstedt 24.9.1945. ${ }^{62}$ På fødevaremærkekortet fik Telling også overstreget stats- 


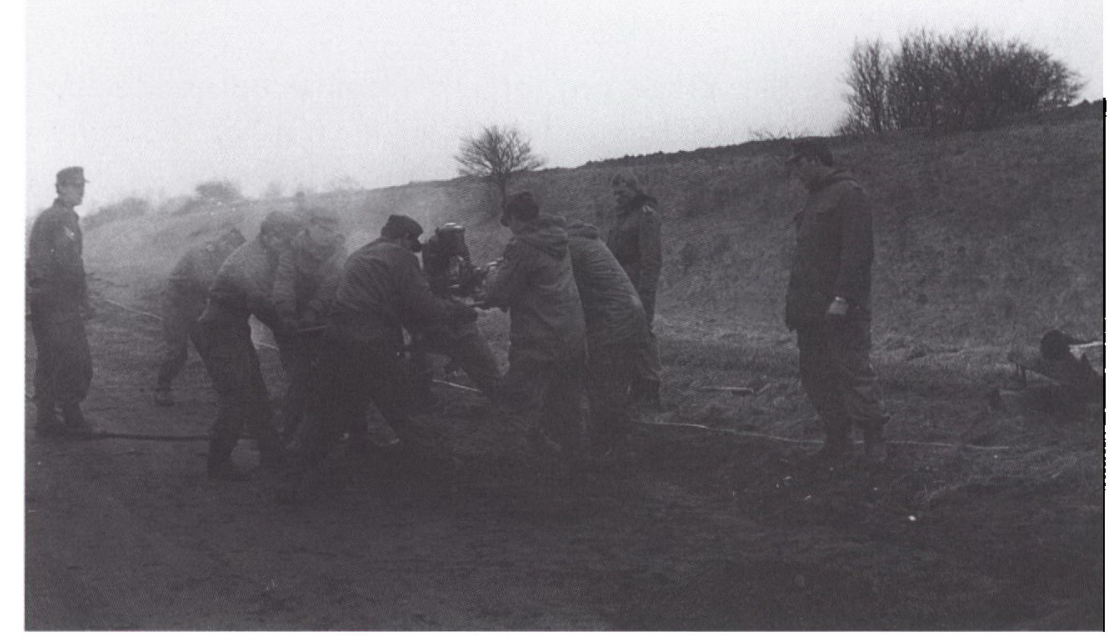

Kort tid for sin dod kunne Soren Telling se et lange naret anske opfyldt: I 1968 opsatte vesttyske soldater hegn omkring Danevirke. Foto: Søren Telling 1968. Negativet findes $i$ Arkivet ved Dansk Centralbibliotek for Sydslesvig.

borgerskabet »tysk « og erstattet med dansk, hvilket blev gjort af borgmesteren i Owschlag i overensstemmelse med de britiske besættelsesmyndigheders regler. Telling havde ganske vist frasagt sig sit danske statsborgerskab i 1941 - men gik den, så gik den vel. Indsatsen til gavn for fortidsminderne nød også godt af det gamle danske pas nr. 115-1940, der var udstedt af det danske generalkonsulat i Flensborg 15.10.1940 og ville have været gyldigt til og med 14.10.1945, såfremt Telling ikke havde skiftet statsborgerskab. ${ }^{63}$ Men det behøvede han jo ikke fortælle, at han havde gjort. Så med det ugyldige danske pas i hånden fik han 20.11.1945 udstedt et bevis af Royal Air Force, der bevidnede hans danskhed og gav ham fri adgang til at foretage arkæologiske undersøgelser. ${ }^{64}$

Søren Telling flyttede 10.10 .1946 fra sit hus i Owschlag til ovennævnte militærbarak på selve volden ved Kurborg. Det skete som led i et "mageskifte", idet de flygtninge, der hidtil havde boet i barakken, nu flyttede ind $\mathrm{i}$ Tellings hus i stedet. Herefter kunne han dagligt fore tilsyn med voldene og varetage den funktion, han havde fået pålagt 
af såvel Slesvig-kredsen som museumsmyndighederne. Han gjorde sig omgående meget upopulær blandt de stedlige bønder, idet han både gjorde opmærksom på misbrugen af volden til græsning, opdyrkning og afgravning og aktivt forsøgte at forhindre denne.

I forbindelse med disse aktiviteter måtte myndighederne i 1948 sande, at Danevirke slet ikke var fredet. Derpå tog Telling på ny affære og pressede sammen med oldtidsmuseet, der i 1947 var flyttet ind på Gottorp Slot i Slesvig, ${ }^{65}$ på over for myndighederne. Han fik god støtte af Jens Nydahl, der var landesdirektor og ansvarlig for regionen Sydslesvig ved delstatsregeringen i Kiel. ${ }^{66}$ Nydahl udnævnte en kommission, der skulle undersøge forholdene - og i sidste ende mundede denne proces ud i en fredningsforordning udstedt af den afgående SPD-regering under ministerpræsident Bruno Diekmann. Forordningen blev bekendtgjort den $2.8 .1950 .{ }^{67}$ Herefter blev det forbudt at ødelægge voldene. Danevirke kunne indhegnes og beskyttes. I de følgende år blev fortidsmindet genoprettet på de steder, hvor det havde lidt synligt overlast. Igen spillede Søren Telling en ikke ubetydelig rolle, idet han f.eks. med sin opfindsomhed var i stand til at fremskaffe græsfrø fra Hunsballe Frøcentral i Danmark, så der hurtigt kunne vokse græs hen over de reparerede voldskråninger. ${ }^{68}$

Selv om Danevirke var blevet fredet i 1950, kunne det heller ikke i de følgende år helt forhindres, at volden led overlast som følge af pløjning, regulært hærværk eller byggeprojekter. Søren Telling forsøgte efter bedste evne at agere "vagthund " og standse disse beskadigelser. ${ }^{69}$ Det var også ham, der i forlængelse af det dansk-tyske arbejde i Danevirke-udvalget tog initiativ til, at voldanlægget blev indhegnet. Han henvendte sig i sommeren 1966 til danske fonde og bad om finansiel støtte til sikring af volden. Da den ene fond imidlertid afslog under henvisning til, at Danevirke-udvalget ifølge dens oplysninger havde tilstrækkeligt med midler til et sådant projekt, kontaktede Telling Danfoss' grundlægger Mads Clausen i stedet. Mads Clausen kunne hurtigt overbevises og udstedte fluks en check på DM 30.000.70 Senere blev der så omsider opsat hegn omkring Danevirke. Denne gang var det tyske soldater, der stod for arbejdet.

\section{"Jarlen på Danevirke«}

Søren Telling blev efter 1945 til "Jarlen på Danevirke«, der med stor dramatisk fortællebegavelse kunne levendegøre voldenes historie. 
Selv om han nogle steder betegnes som »inspektør på Danevirke«, er det ikke helt korrekt. Telling var fra september 1945 ulønnet medarbejder ved »Landesamt für Vorgeschichte«. Men han inspicerede rigtigt nok Danevirke. Og han var som ægte idealist hårdnakket i forhandlingerne med de tyske myndigheder. De ville helst slippe af med ham, men efterhånden voksede respekten for hans indsats for voldanlægget. Han kendte som ingen anden Danevirke. Han gennemførte mindst én gang om måneden en udstrakt inspektionstur på voldene på sin motorcykel for at tilse dens tilstand - og slå alarm, når volden led overlast.

Ifølge egne optegnelser havde Telling også andel $i$, at direktøren for Nationalmuseet i København, Johs. Brøndsted, i 1955 blev medlem af det særlige Danevirke-udvalg, der skulle føre tilsyn med voldanlægget og afgive ekspertiser $i$ forbindelse med anlægsarbejder etc. Det skete som følge af et forbedret dansk-vesttysk-slesvig-holstensk forhold efter Bonn-København-erklæringerne om det danske og tyske mindretals rettigheder i 1955. Brøndsted blev vitterligt medlem - og da den daværende slesvig-holstenske ministerpræsident Kai-Uwe von Hassel i 1958 aflagde rapport over Bonn-erklæringens virkeliggørelse, fremhævede han netop rigsantikvarens medlemskab i Danevirkeudvalget. ${ }^{71}$

Selv om Telling ikke blev dansk statsborger igen, vendte han på sin vis alligevel tilbage $\mathrm{i}$ dansk offentlig tjeneste. Han blev nemlig instruktør $\mathrm{i}$ trommeslagning ved jyske regimenters musikkorps $\mathrm{i}$ årene 1955-65. Ved Jydske Fodregiments 300-års jubilæum i 1965 slog han som 70-årig tappenstreg i sin korporalsuniform fra 1917. Samtidig blev han udnævnt til ingeniørregimentets ærespioner nr. 2 i Randers. $^{72}$

Telling satte således sit præg på Danevirke efter 1945 og frem til sin død i 1968. Han fik stor betydning for, at volden ikke blev beskadiget yderligere - og fik da også et særdeles positivt eftermæle i nekrologer og samtidiges syn på hans personlighed. DNSAP-medlemskabet blev glemt eller fortrængt og forbløffer $i$ dag mange, der har kendt ham og uden tøven vil betegne ham som "god dansker«. Endnu en af de mange forbløffende, modstridende, sammensatte og vanskeligt udgrundelige facetter af Danevirkes historie. Tellings bevæggrunde lå i en pointeret dansk nationalisme. Han blev betaget af Danevirke og tilegnede sig voldanlægget på et tidspunkt, hvor han ifølge en række vidnesbyrd selv personligt havde gjort op med den nazistiske ideo- 
logi og på ny hengav sig til dansk nationalistisk tænkning. Danevirke lutrede således på sin vis Telling. Han lagde afstand til sin nazistiske verdensanskuelse, der konkret havde medført medlemskab i DNSAP $i$ årene 1935-41. I stedet fokuserede han på den danske oldtid og frem for alt andet på Danevirke.

Søren Telling boede på Danevirke og døde også dér i juli 1968. ${ }^{73}$ Han levede de sidste 25 år af sit liv for Danevirke. Han viede hele sin gerning til fortidsmindet og følte sig ikke blot som Danmarks "vagthund ", men blev også i levende live til "Jarlen på Danevirke“. Mange danskere, der i tiden 1945-68 besøgte Danevirke som enkeltpersoner eller i forbindelse med ekskursioner, har selv oplevet Telling fortælle på og om Danevirke. Den dag i dag bevidnes det, at der udgik en særegen fascination fra denne unikke personlighed med de mange facetter. Dette medgives også af ældre tyske bønder, der i sin tid har stiftet bekendtskab med Telling og dennes kontante og bryske fremfærd over for dem, når de kom volden for nær.

\section{LITTERATUR}

Bettina Arnold/Henning Hassmann: Archaeology in Nazi Germany: the legacy of Faustian Bargain. i: Nationalism, Politics, and the Practice of Archaeology, Cambridge 1996, s. 70-91.

Carla Christensen: Med søster Carla til fronten. Kjellerup Kunstforenings forlag 1998.

Danevirke endelig fredet. Det brændende Spørgsmaal, 9, 1950.

Dansk Musiker-Tidende. 16.6.1950, s. 193.

En hædersmand. Randers Amtsavis, 11.3.1965.

Günther Haseloff: Die Ausgrabungen am Danewerk und ihre Ergebnisse. Offa, Band 2, Neumünster 1937.

Henning Haßmann/Detlef Jantzen: "Die deutsche Vorgeschichte - eine nationale Wissenschaft «. Das Kieler Museum vorgeschichtlicher Altertümer im Dritten Reich. Offa, Bd. 51, Neumünster 1994, s. 9-23.

Lars N. Henningsen/Martin Klatt/Jørgen Kühl: SSW. Dansksindet politik i Sydslesvig 1945-1998, Flensborg 1998.

Mathias René Hofter: Graben für Germa- nien. Die deutsche Vor- und Frühgeschichte im Nationalsozialismus. Frankfurter Allgemeine Zeitung, 9.12.1998.

Johan Hvidtfeldt: Heinrich Himmler og mindesmærkerne ved Danevirke. Sønderiyske Årbøger 1964, s. 467-476.

Herbert Jankuhn: Die Wehranlagen der Wikingerzeit zwischen Schlei und Treene, Neumünster 1937.

Jørgen Jensen: Manden i kisten, København 1998.

Michael H. Kater: "Das Ahnenerbe" der SS 1935-1945. Ein Beitrag zur Kulturpolitik des Dritten Reiches, Stuttgart 1974.

Jørgen Kühl og Nis Hardt: Danevirke, Herning 1999.

John T. Lauridsen: "Vikingernes sande efterkommere«, Magasin fra Det kongelige Bibliotek, 7. årg., 4, marts 1993, s. 15-28.

John T. Lauridsen: Nazitræf i Kolding 1939 - om politisk kultur og partipolitisk teater. Fortid og Nutid, 4, december 1994, s. 357-376.

Michael Müller-Wille: Der politische Mißbrauch der skandinavischen Vor- und 
Frühgeschichte während der Jahre 1933-1945, Offa, Bd. 51, Neumünster 1994, s. 25-35.

Telefonsamtale med Himmler reddede Danmarks gamle Led. Vejle Amts Folkeblad, 26.1.1965.

Soren Telling: Danevirke truet endnu engang. Det brændende Spørgsmaal, 4, 1953 [Telling 1953a].

Søren Telling: Omsider blev Danevirke fredet. Det brændende Spørgsmaal, 5, 1953 [Telling 1953b].

Soren Telling: 15 års strid for voldenes fred. Det brændende Spørgsmaal, 5, 1961.

Tage Mortensen (red.): Soren Telling. Om og af den danske jarl på Danevirke. Sydslesvigsk Forening, Flensborg 1969.

30-årskrigen om Danevirke. Samvirke, 13, 1.8.1967.

Voldens Vogter - og hans danske Daad, Jyllands-Posten, 24.1.1965.

Nils Vollertsen: Herbert Jankuhn, Hedebyforskningen og det tyske samfund 19341976. Fortid og Nutid, 36, 4, 1989, s. 235250.

Stine Wiell: Flensborgsamlingen 18521864 - og dens skæbne. Studieafdelingen ved Dansk Centralbibliotek for Sydslesvig, Flensborg 1997.

Zur Eröffnung der Landesmuseen in Schloss Gottorf. Schleswig-Holstein. Monatshefte für Heimat und Volkstum. August-Heft, Jahrgang 1950.

Desuden er Privatarkivet P 24 Søren Telling og P 260 Jørgen Jørgensen og Institutionsarkivet I 61 Dansk Generalsekretariat DGS i Arkivet ved Dansk Centralbibliotek for Sydslesvig, Flensborg, blevet anvendt.

\section{NOTER}

1. Artiklen bygger på bl.a. person- og institutionsarkiver $i$ Arkivet ved Dansk Centralbibliotek for Sydslesvig i Flensborg. Soren Tellings privatarkiv har kunnet benyttes efter tilladelse fra sønnen Rasmus Telling. Forkortelsen DCB står i det folgende for Arkivet ved Dansk Centralbibliotek for Sydslesvig.

2. Jankuhn 1937 og Haseloff 1937 dokumenterer de arkæologiske underse- gelser, der under stor bevågenhed fra ledende nazistisk hold blev foretaget i området i 1930erne.

3. Haßmann/Jantzen 1994. Se desuden Hofter 1998, Jensen 1998, Kater 1974 og Müller-Wille 1994, se tillige Arnold/Hassmann 1995.

4. Haßmann/Jantzen 1994, s. 10.

5. Hofter 1998; Haßmann/Jantzen 1994, s. 10.

6. Haßmann/Jantzen 1994 , s. $15 \mathrm{f}$.

7. Vollertsen 1989, s. 235.

8. Haßmann/Jantzen 1994, s. 11.

9. Haßmann/Jantzen 1994, s. 16.

10: Kater 1974, s. 290.

11. Haßmann/Jantzen 1994, s. $19 f$.

12. En overgang stod Telling helt alene for en af disse udgravninger i Ukraine. Denne er beskrevet $i$ et manuskript samt et større antal negativer $i$ Søren Tellings arkiv DCB P 24.

13. Denne fremstilling bygger på Hvidtfeldt 1964.

14. Hvidtfeldt 1964, s. $468 \mathrm{ff}$.

15. Hvidtfeldt 1964, s. $469 \mathrm{ff}$.

16. Hvidtfeldt 1964 , s. $470 \mathrm{ff}$.

17. Hvidtfeldt 1964, s. 473ff.

18. Citeret efter facsimile i Hvidtfeldt 1964, s. 474.

19. Dette begivenhedsforløb beskrives udførligt af Søren Telling selv i Telefon til Himmler, Mortensen 1969 s. 2934.

20. Se også Dansk Musiker-Tidende 1950.

21. Erindringsmanuskriptet, s. 27. DCB P 24.

22. Episoden genfortælles af Carla Christensen i Med søster Carla til fronten 1998, s. 38. Carla Christensen var på dette tidspunkt ung pige $i$ huset hos Frits Clausen i Bovrup i Sonderjylland.

23. Lauridsen 1994, s. 361ff.; se også Lauridsen 1993.

24. Telling skriver i Mortensen 1969, s. 174-177 om disse studier uden blot at antyde den ideologiske sammenhæng. Til gengæld meddeles, at Brøndsted var leder af disse forsøg.

25. Kopi af Søren Tellings ansøgning af 5.8.1938 og Johannes Brøndsteds skriftlige tilladelse af 3.1.1939 findes i DCB P 24.

26. Erindringsmanuskriptet, s. 27 i DCB P 24. 
27. Søren Telling: Tidstavle over mit liv fra 1939, 6.2.1946, DCB I 61.

28. Oplyst af Rigspolitiet til Dansk Generalsekretariat, bevaret i DCB I 61 .

29. Soren Telling: Tidstavle over mit liv fra 1939, 6.2.1946, DCB I 61.

30. I Tellings erindringsmanuskript, s. 27, hævdes det imidlertid, at han afviste medlemskab i NSDAP pga. sin danskhed. DCB P 24.

31. Dokumentet er bevaret i Søren Tellings privatarkiv DCB P 24.

32. Soren Telling: Tidstavle over mit liv fra 1939, 6.2.1946, DCB I 61.

33. Erklæring afgivet af Karl Kersten, 18.1.1948, afskrift af 10.7.1952 i DCB P 24.

34. Wiell 1997, s. 234ff.

35. Erklæring af Karl Kersten, 1.6.1946, kopi i DCB P 24.

36. Erklæring afgivet af Karl Kersten, 18.1.1948, afskrift af 10.7.1952 i DCB P 24.

37. Netop Gustav Schwantes afslører imidlertid i 1957 i et personligt brev til Søren Telling et verdenssyn, hvori nazismen ikke er den største skurk: "Der größte Zerstörer Europas, Churchill, gilt als einer der größten Helden unseres Zeitalters und empfängt von uns Deutschen sogar in Aachen einen Preis! «. Gustav Schwantes til Søren Telling, 1.3.1957, DCB P 24.

38. Jensen 1998 , s. 162.

39. Oplyst i DCB P $260-12 a$.

40. Frants Thygesen til E. F. S. Knudsen, 4.4.1955, kopi i DCB P 24.

41. Det skete med ansættelsesbrev af 30.11.1945 underskrevet af Svend Johannsen på vegne af den Slesvigske Forening i Slesvig by, bevaret i DCB P 24.

42. Frants Thygesen til E. F. S. Knudsen, 4.4.1955, kopi i DCB P 24.

43. Tage Jessen, vidnesbyrd vedrorende Srren Telling, 7.2.1946, DCB I 61.

44. Anbefaling forfattet af Johannes Brondsted, 13.7.1960, kopi i DCB P 24.

45. DCB P 24.

46. Citeret efter Søren Tellings egen fremstilling i Mortensen 1969 s. 32.

47. Telegrammet er bevaret i Seren Tellings arkiv DCB P 24.

48. Se f.eks. Telling 1953a.

49. Citeret efter Telling 1953b. Der findes dog også - ligeledes fra Tellings mund - en anden version af Knochenhauers reaktion: "Med dette makværk har De kun opnaaet at ærgre og fortrædelige en venligtsindet nabostat. Jeg raader Dem snarest til at dække det hele til igen«, citeret $\mathbf{i}$ Telefonsamtale med Himmler 1965.

50. Haßmann/Jantzen 1994, s. 20.

51. Kater 1974, s. 291.

52. F.eks. Telefonsamtale med Himmler 1965, der i identisk ordlyd også findes i Demokraten, 30.1.1965; Voldens Vogter 1965. Samme version findes ogsả hos Hvidtfeldt 1964, s. 476, note 8.

53. Se Kater 1974, s. 439.

54. Karl Kersten: Zeugnis, 12.9.1945, udstedt til Søren Telling, DCB P 24.

55. Erklæring aflagt af Karl Kersten, 18.1.1948 $\mathrm{i}$ afskrift af 10.7.1952, DCB P 24.

56. Gustav Schwantes til Søren Telling, 12.9.1945, DCB P 24.

57. Søren Telling: Tidstavle over mit liv fra 1939, 6.2.1946, DCB I 61.

58. Telling 1953b giver en redegerelse for hele dette forlab. Se også Mortensen 1969 s. 58-83. vedr. istandsættelsen af Kovirke og Danhøjene.

59. Kreis Schleswig til Soren Telling, 30.9.1946, DCB P 24.

60. Kreis Schleswig til Søren Telling, 9.3.1950, DCB P 24.

61. "Ausweis" udstedt af Gustav Schwantes, 2.5.1945, DCB P 24.

62. Dokumentet findes i hans privatarkiv DCB P 24.

63. Passet findes $i$ velholdt stand, men uden et åbenbart udrevet identifikationsfoto i Søren Tellings arkiv DCB P 24.

64. Dokumentet findes i DCB P 24.

65. Vedrørende flytningen af Kieler-museet til Gottorp Slot se temaudgaven "Zur Eröffnung der Landesmuseen in Schloss Gottorf «, Schleswig-Holstein, August 1950.

66. Se også Telling 1953b.

67. Se f.eks. Danevirke endelig fredet 1950; Telling 1961.

68. Jvf. Telling 1961.

69. Se også Mortensen 1969, s. 36-56.

70. Erindringsmanuskript, s. 57, DCB P 24. 
71. Henningsen/Klatt/Kühl 1998, s. 230.

72. Se En hædersmand 1965.

73. Se om Tellings positive eftermæle Mortensen 1969, s. 201ff. Her karakte- riseres han bl.a. med ord som $"$ vogter og værner", "nidkær dansker", "viking «, "jarlen på Dannevirke og »en kriger $\times$. 